\title{
EQUITY MANAGEMENT OF THE TOURISM SECTOR ENTERPRISES IN THE SLOVAK REPUBLIC
}

\author{
Katarína Tasáryová ${ }^{1}$ \\ Renáta Pakšiová ${ }^{2}$ (1)
}

DOI: https://doi.org/10.31410/tmt.2020.147

\begin{abstract}
Since its expansion at the beginning of the 20th century, tourism has shown its strength and importance. Tourism is a link between several economic sectors, thanks to its accumulated development potential. One of the main goals of business entities from the financial point of view is to achieve profit. The second is the maximize the value of the company, which can be affected by the achievement of profit. Companies operating in the field of tourism in the Slovak Republic are no exception. The chapter deals with the analysis of their equity, including its individual items with an emphasis on the going concern. Using Pearson's correlation coefficient, we identify the relationship between equity and its individual items. The aim of the chapter is, based on indebtedness indicators, specifically total indebtedness and the degree of self-financing to assess the adequacy of own resources needed to finance its activities in this sector in the Slovak Republic, while marginally analyzing the impact of COVID-19 on the tourism sector in Slovakia.
\end{abstract}

Keywords: Share capital, Retained earnings, Profit, Loss.

\section{INTRODUCTION}

$\mathrm{U}$ pon entering the market, each company must be financed by capital, while it must own such forms of assets through which its business activities will be carried out. At the beginning of the business, the capital structure is always dominated by the own resources of the assets invested in the company by the partners as equity. However, this state of financing the company's activities is unsustainable in the long run and does not reflect the normal situation of its operation on the market. Companies usually do not have a sufficient amount of their own resources, so they have to raise capital from the external environment in the form of extraneous resources. Raising capital to finance the operation of a company is considered to be one of the biggest problems. For a company, the selection of its sources of financing is a lengthy process that costs it a lot of effort. Resources of financing can come from the internal environment of the company, i.e. they are created directly in the company or they are obtained in various forms from the external environment. It is the right setting of the ratio of own and extraneous resources of financing that is the biggest challenge in the business sphere. It can be assumed to a large extent that it depends on the subject of business and the industrial segment. This chapter aims to analyze the capital structure of entrepreneurs in the tourism industry in the Slovak Republic in terms of its impact on financing the company's activities. Using Pearson's correlation coefficient, the authors identify the relationship between equity and its individual items. In the chapter, the authors will also present aspects related to the current situation of the impact of Covid-19 and measures of the Government of the Slovak Republic on the situation of entrepreneurs in the tourism industry in the Slovak Republic.

\footnotetext{
$1 \quad$ University of Economics in Bratislava, Dolnozemská cesta 1, 85235 Bratislava, Slovakia

2 University of Economics in Bratislava, Dolnozemská cesta 1, 85235 Bratislava, Slovakia
} 


\section{RESOURCES OF ASSETS FROM ECONOMIC AND ACCOUNTING PERSPECTIVES}

The resources of assets can be viewed in two ways, while the first method examines the resources of assets in terms of the origin of assets, where we are interested in the perspective of the entity, based on which the resources of assets are divided into own and extraneous. By own resources of the company, authors mean its equity, which is created in some companies at the moment of launching the business. Extraneous resources include liabilities, loans, and borrowings. The second method is the legal aspect, according to which the resources of assets represent the claims of third parties (suppliers, the state, banks, owners, etc.) against the entity. Equity is an abstract concept and does not apply to specific types of assets. The reason is the fact that at every moment of the asset cycle, we would have to assign different assets to our equity, which is practically impossible. Because of the above, equity is quantified as a whole, specifically as the difference between assets and liabilities, which we refer to as the modified extended balance sheet equation. This relationship is an indirect definition of equity, as equity is defined in this case as the difference between two other specifically defined components of the balance sheet, namely assets and liabilities (Šlosárová, 2018).

In section 2(2) of Act no. 431/2002 Coll. on Accounting, as amended in the Slovak Republic (hereinafter referred to as the „Accounting Act"), it is stated in general that the subject of accounting is the accounting of facts, including the difference between assets and liabilities, a specification of this term can be found in section 59(1) of the Measures of the Ministry of Finance of the Slovak Republic 23054/2002-92, which lays down details on accounting procedures and general chart of accounts for entrepreneurs accounting in the double-entry bookkeeping system as amended (hereinafter referred to as accounting procedures), in which it is precisely defined that equity represents the difference between assets and liabilities. By equity, we mean the own resources existing in the company throughout the implementation of business activities, which should be available to the company at all times, as they are long-term resources. The volume of equity is crucial for determining the long-term survival of the company (Valaskova et al., 2019).

In terms of the time of entry into the company, equity can be divided into two basic parts (Máziková et al., 2016). The first part includes the part invested in the company at its establishment, where the initially invested capital of individual owners can be included in the business. The second part relates to the very period of existence and includes internal resources, external resources, and resources acquired in another form. By internal resources, we mean resources created by the entrepreneur's own activity, when he tries to make a profit, which leads to an increase or decrease in equity. External resources are resources that the company has obtained through other owners' contributions to equity, for example in the form of gifts from shareholders. Resources acquired by the company in another form may include valuation differences arising from the revaluation of certain types of assets and liabilities following the Accounting Act, share premium representing the difference between the nominal value of shares and the issue price, and others (Šlosárová, 2016). The process of creating own resources in the course of business activity is referred to as self-financing.

The most important component of equity is considered to be the share capital defined in section 58(1) of Act no. 513/1991 Coll. Commercial Code in the Slovak Republic (Commercial Code, 2020) as amended as a monetary expression of the sum of monetary and non-monetary deposits of all partners in the company. The shareholder's contribution (Commercial Code, 2020) means 
the sum of funds and other money-valued assets that the shareholder invests in the company and shareholders contribute to the company's business results. The share capital must be created by limited liability companies, joint-stock companies, and simple stock companies, and its amount is entered in the Commercial Register of the Slovak Republic (Section 58 (2) of the Commercial Code). We account for individual items of equity (Table 1) on accounts of account class 4 - Capital accounts and long-term liabilities containing account groups $41-43$ of the General Chart of Accounts for Entrepreneurs in the Slovak Republic (Accounting Procedures, 2020)

Table 1. Account groups and equity accounts

\begin{tabular}{|c|c|}
\hline Account group number and name & Account number and name \\
\hline 41 - Share capital and capital funds & $\begin{array}{l}\text { - } 411 \text { - Share capital } \\
\text { - } 412 \text { - Share premium } \\
\text { - } 413 \text { - Other capital funds } \\
\text { - } 414 \text { - Valuation differences from a revaluation of } \\
\text { assets and liabilities } \\
\text { - } 415 \text { - Valuation differences from equity investments } \\
\text { - } 416 \text { - Valuation differences on mergers, acquisitions, } \\
\text { and divisions } \\
\text { - } 417 \text { - Legal reserve fund from capital deposits } \\
\text { - } 418 \text { - Indivisible fund from capital deposits } \\
\text { - } 419 \text { - Changes in share capital }\end{array}$ \\
\hline $\begin{array}{l}42-\text { Funds created from profit and transferred } \\
\text { economic results }\end{array}$ & $\begin{array}{l}\text { - } 421 \text { - Legal reserve fund } \\
\text { - } 422 \text { - Indivisible fund } \\
\text { - } 423 \text { - Statutory funds } \\
\text { - } 427 \text { - Other funds } \\
\text { - } 428 \text { - Retained earnings } \\
\text { 429 - Unrecovered loss }\end{array}$ \\
\hline 43 - Profit/loss & - 431 - Management result in approval \\
\hline
\end{tabular}

Source: own processing according to the General Chart of accounts in the Slovak Republic

(Accounting Procedures, 2020)

All components of an entity's equity are recognized in the financial statements in the balance sheet on the liabilities side. Explanations of changes in equity are included in the financial statements compiled according to the national accounting legislation in Slovakia in the notes as part of the financial statements. In the case of IFRS's financial statements, the information of equity is published in the statement of changes in equity, which is a part of the financial statements. Accounting entities in the Slovak Republic publish financial statements in the Register of Financial Statements of the Slovak Republic.

\section{TOURISM}

In general, tourism is considered to be one of the largest industries in the world (Wallace \& Russel, 2004; Saarinen, 2006). Tourism, as an important industrial sector, has undergone several changes in its development, including a change in structure and properties as well as the acquisition of some new functions (Šapić et al., 2018). Tourism is an essential part of each country's national economy from an economic point of view (Štefko et al., 2018). Tourism is a link between several economic sectors, thanks to its accumulated development potential (Beránek, 2013). Gligorijević \& Stefanović (2012) define tourism as a type of consumer movement that is aimed at meeting the specific needs of people, while they understand specific needs as tourist needs. Tourism is a spatial phenomenon with a major impact on society and various sectors of the national economy, such as construction, transport, and trade (Zarebski et al., 2019). Tourism, 
by Šambronská (2017), means a complex industry, including everything that goes with it in addition to fierce competition, i.e. product, promotion, specific models, sales, partnerships, technologies. Tourism can contribute to regional economic growth by providing favorable conditions for tourism development in regions where the prospects for other sectors of the economy are quite unfavorable (Neumeier \& Pollermann, 2014). According to Brida et al. (2010) tourism in some way supports and leads to long-term economic growth, which is referred to as the tourism-oriented growth hypothesis Claveria \& Datzira (2009) consider it necessary to identify the factors determining demand at the tourist level, as according to them tourism is generated by demand. Regardless of the level of economic development, each country is interested in tourism due to various positive impacts, such as developing economic growth, promoting international understanding and peace, improving living standards, stimulating local trade and industry, protecting cultural heritage, and so on (Goeldner et al., 2000; MacGregor Pelikánová, 2019; Turečková \& Nevima, 2019). According to Čačić (2013) tourism belongs to the modern socio-economic phenomenon with significant economic, political, cultural or other influences, thanks to which it plays an important role in the overall economic and social development worldwide.

Seasonality, which is one of the most undesirable companions due to the significant negative effects it causes, can be considered a general feature of tourism (Petrevska \& Nikolovski, 2018). There are several ways to measure seasonality in tourism, most often using estimates of seasonal factors in time series, proportional deviations from moving averages over fictitious variables in several linear regressions, or using more advanced econometric models (Fernández-Moralez, 2003; Ashworth \& Thomas, 1999). According to Lundberga et al. (1995), seasonality can occur as systematic changes not only during the year but also within a month, a week, even in one day.

The main difficulty in measuring the economic impact of tourism is the multisectoral nature of tourism activity, which brings quantifiable benefits and which somehow reduce the true contribution of tourism to economic development (Meyer, 2004). Brida (2008) emphasizes the lack of a sectoral statistical tool at a transnational level that could provide a sufficiently structured database to allow further research integrating data from the satellite tourism accounts of different countries, which represents a more realistic approach to the tourism sector.

Several authors have dealt with the classification of tourists in their scientific studies, and Plog (2001) divides tourists into three groups according to their preferences. The first group includes cautious tourists who prefer shorter trips, who like safety and do not travel often. Careful tourists choose well-planned tours, buy lots of souvenirs and stay in cheaper hotels or motels. If in the past they were satisfied with the choice of destination, they often return there. The second group is represented by brave tourists who avoid the crowd who prefer traveling and exploring, go on longer trips (independent trips, active holidays, adventure activities), they like to get to know the customs and habits in the destinations they visit. The last group includes tourists with similar habits as in the previous two groups, depending on which group they are closer to.

Modern tourism has several interconnected functions forming an indivisible whole with a strong impact on the economic life of the country, while Dobre (2005) divides them into two groups (Table 2).

According to Steck (2010), the wider economy is affected by the direct effects of tourism, which it has divided into six categories. The first category is the creation of jobs that arise as a result of the development of tourism, such as the position of hotel staff, chefs, travel agency staff, and the 
like. The second category is the supply of goods and services that local or national businesses can offer to tourist businesses (food, furniture, etc.), and these items may be imported if local provisions fail to meet the demand for costs, quality or quantity. The third category includes the sale of goods and services by retailers in tourist destinations, such as the sale of souvenirs or food, which directly captures the cash flows from tourist activities. The fourth category concerns the establishment of tourism companies due to the high or increasing level of tourism activities. The penultimate category refers to taxes and levies where tourism companies contribute (national indirect taxes). The last category is an investment in infrastructure, the increase in which is conditioned by the growing demand in the field of tourism to increase local infrastructure, either by private actors or the public sector.

Table 2. Basic functions of tourism

\begin{tabular}{|c|c|}
\hline \multirow{4}{*}{ Economic functions of tourism } & $\begin{array}{l}\text { Direct impact on: } \\
\text { - social product and national income } \\
\text { - faster development of underdeveloped areas } \\
\text { - balance of payments } \\
\text { - employment }\end{array}$ \\
\hline & $\begin{array}{l}\text { Indirect impact on: } \\
\text { - industry } \\
\text { - construction } \\
\text { - agriculture }\end{array}$ \\
\hline & $\begin{array}{l}\text { Multiplicative impact: } \\
\text { - export }\end{array}$ \\
\hline & Other impacts \\
\hline Non-economic functions of tourism & $\begin{array}{l}\text { - health function } \\
\text { - entertainment function } \\
\text { - cultural function } \\
\text { - social function } \\
\text { - } \text { political function } \\
\text { - function in relation to the defense of the country }\end{array}$ \\
\hline
\end{tabular}

Source: Dobre, 2005

\section{THE POSITION OF THE TOURISM INDUSTRY IN THE SLOVAK REPUBLIC AS AN EU MEMBER}

The European Union is a unique economic and political partnership between the 27 countries ensuring peace, stability, and prosperity on the European continent, contributing to the rising standard of living of its citizens, establishing a single European currency, and continuing to build a single European market in which the free movement of people, goods, services and capital between member countries is as self-evident as within countries (Staníčková \& Melecký, 2018; Cvik \& MacGregor Pelikánová, 2015).

Santos \& Cincera (2018) state that tourism is one of the three largest socio-economic activities in the European Union and makes a significant contribution to the European Union's gross national product and employment. Europe is one of the number one tourist destinations (Roman et al., 2020). However, Europe is not one of the fastest-growing regions in the global industry and its market share is declining, taking into account international arrivals and tourist revenues (Juul, 2015). Research in the field of tourism needs to take into account the dynamics of the sector, such as various aspects such as eradicating poverty and hunger, ensuring sustainable economic growth, decent work, improving the quality of education, increasing health and well-being, promoting a sustainable ecosystem, maintaining inclusive, safe and sustainable places, including infrastruc- 
tures to support industrialization and the like (Moreno \& Tovar, 2015). The Member States of the European Union have competitive interests in the development of tourism (MacGregor Pelikánová, 2019). Tourism is not a contracted competence; it is one of the components of regional policies of individual member states. The European Union carries out support, coordination or complementary activities in tourism (Gúčik, 2011). Pay attention to the tourism sector in the institutions of the European Union, while ensuring greater coordination of activities and analysis of the impact of the various European Union directives in its policies on the sustainable development of tourism in Europe (Kučerová et al, 2010; MacGregor Pelikánová \& MacGregor, 2017).

The Slovak Republic, with the capital city Bratislava, joined the European Union on May 1, 2004. The country is divided into 8 regions, each named after its site (Figure 1). According to the information on the website of the European Union (2020), the most important sectors of the Slovak economy in 2018 were industry (26.2\%), wholesale, retail trade, transport, accommodation and food services $(20.2 \%)$, public administration, defense, education, health and social work (14.8\%).

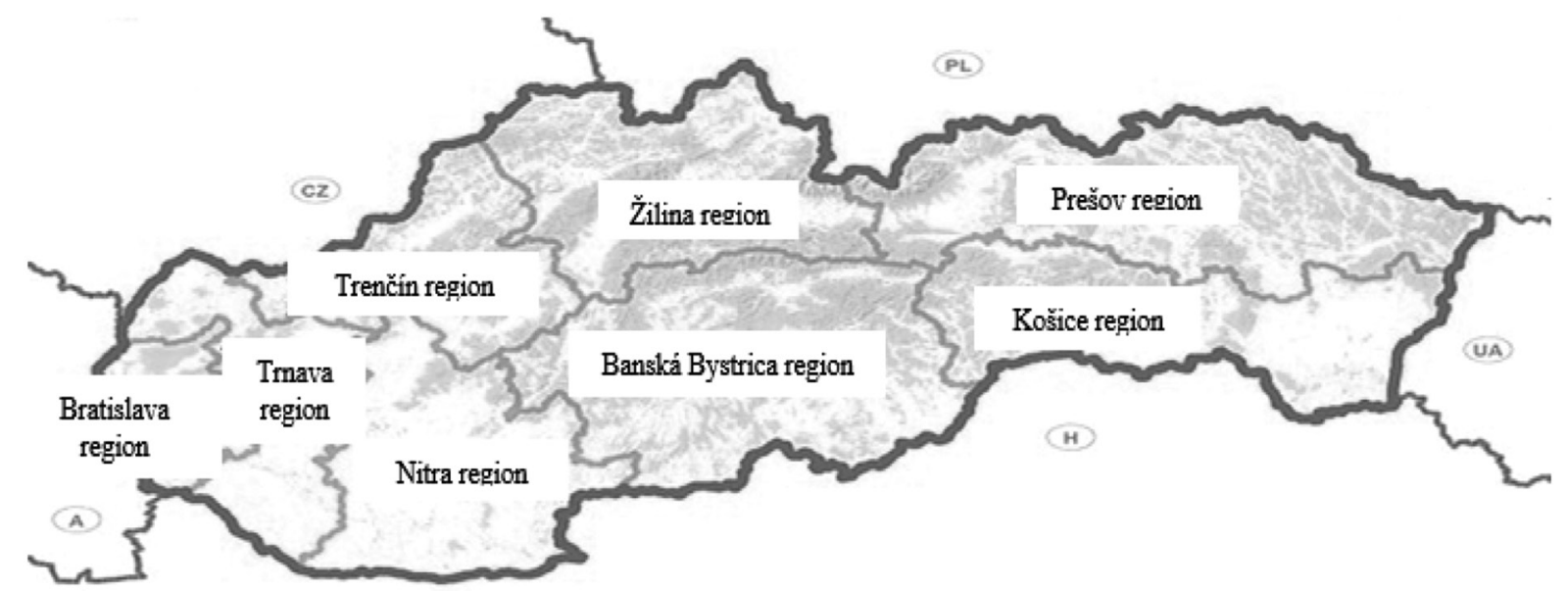

Figure 1. Slovak regions

Source: CDB SK, 2020

In terms of the possibilities provided by the territory of the Slovak Republic, in the range of altitude from $94.3 \mathrm{~m}$ above sea level to $2,655 \mathrm{~m}$ above sea level, according to the strategy of tourism development in 2020, the cultural, historical, and natural potential of tourism in Slovakia, in the long run, predetermines the main types of tourism, which include (Ministry of Transport and Construction of the Slovak Republic, 2020):

- summer tourism - the motive for tourists is mainly to stay by the water, they visit swimming pools, aqua parks or various water areas. Other motives include rest, relaxation, hiking in mountain resorts, but also the effort to gain new knowledge, get to know new regions and areas. Last but not least, the need for exercise as part of a healthy lifestyle should be mentioned, which from a territorial point of view means that the development of tourism can also take place in areas where they have been underused so far, provided there is sufficiently strong demand;

- winter tourism - in recent years, Slovakia has had a competitive offer for the Central European market, except for Austria, after extensive investments in mountain tourism resorts. Competitiveness is based on geographical conditions and built capacities. As part of the development of winter tourism, it is necessary to increasingly respect the requirements for nature protection, as many resorts are located nearby or directly in protected landscape areas. The High Tatras are considered a special part, where it is 
necessary to complete the planned zoning. Climate change must be respected in the development of mountain tourism resorts, while ski resorts must be built at a minimum valley station altitude of 700-800 meters above sea level;

- spa and health tourism - after socio-political changes in 1989, the Slovak spa industry had the presumption to be the so-called the "flagship" of tourism. Natural healing baths and thermal baths have an irreplaceable role in disease prevention, which at the same time helps to prevent diseases of civilization. Many Slovak spas have included wellness services, weekend beauty stays, stress relief stays, and the like in their programs, even under medical supervision. At the same time, a relatively wide network of thermal baths and aqua parks was built in Slovakia. For the purposes of health tourism, other natural conditions are also used, among which caves can be included, among other things, while in Slovakia there are 12 caves;

- cultural and urban tourism - Slovakia has a relatively large but little-used potential in this area, while the construction and technical condition of historical monuments can be considered an obstacle. Insufficiently developed products include organized events (calendar of events - cultural, sports, and business), which are carried out by cities and municipalities (planning and implementation level). Obstacles may include a weak and insufficient presentation and promotional activity at home or abroad, which is referred to as the marketing of tourism organization;

- congress tourism is one of the most promising and economically lucrative tourism, as it requires not only services directly related to the organization of congresses, conferences, and similar events, but also services of a complementary nature. Slovakia has suitable material preconditions for the development of congress tourism in hotels (modernization of hotels already carried out), which should offer the mentioned services especially in the off-season period, provided that the quality of services is high, together with the accompanying programs;

- rural tourism and agrotourism - rural tourism is associated mainly with simpler forms of accommodation, such as private accommodation, in guesthouses, and the like in the countryside with the possibility of learning about rural life. Part of rural tourism is agrotourism, which is associated with a stay at the farm. In the conditions of Slovakia, it is a relatively undeveloped type of tourism, which is a consequence of previous periods, which are associated with the existence of the state and cooperative farming on the land and the interruption of the tradition of private business in the agricultural sector. Because of the above, it is necessary to use the experience and knowledge from the surrounding countries, as rural tourism is used quite often in the world;

- geoparks and geotourism are one of the possibilities of tourism, due to the geographical diversity and richness of Slovakia. The UNESCO International Organization defines a geopark as an area that contains phenomena of special geological significance, a certain peculiarity or beauty presented depending on the region, geological history, origin, and processes that shaped it. With the use of specific tourism and the so-called geotourism geoparks can be an important aspect for local economic development, which contributes to increased employment and new economic activities of a particular region.

\section{DATA AND METHODOLOGY}

The aim of quantitative research carried out on a sample of financial information of companies operating in the Slovak Republic in the field of tourism for the period 2014-2018, is based on the development of total equity to identify items that resulted in a change in equity with an em- 
phasis on assessing the development in Slovakia. The sources of data relevant for research are mainly the financial statements of individual companies for the period from 2014 to 2018, which are publicly available on the website of the register of financial statements maintained by the Ministry of Finance (Register FS, 2020) as a database of financial information on accounting entities in the Slovak Republic, which is freely available to external users. An additional source of information is Finstat (www.finstat.sk), which provides information on a commercial basis. In addition to the financial statements, it contains more extensive and detailed structured data. In the research, the authors use statistical methods, specifically descriptive statistics of sample indicators such as minimum value, maximum value, median, arithmetic mean, and Pearson's correlation coefficient, based on which the authors identify the relationship between equity and its individual items. The authors use selected indicators to determine the minimum, maximum and average value of equity, profit after tax, total indebtedness, and degree of self-financing. Using the median, we identify the mean value within equity, profit after tax, total indebtedness, and degree of self-financing.

\subsection{Descriptive statistics of the examined sample}

The research is carried out on a sample created from all companies operating in the Slovak Republic selected in the field of tourism, which have published financial statements for the examined periods 2014-2018 and their subject of business is from two divisions of the classification of economic activities, namely 55 - Accommodation and 56 - Activities restaurants and inns. In terms of the structure of the legal form of companies, the largest group consisted of limited liability companies, therefore only limited liability companies are included in the further analysis in the sample. Data on the number of limited liability companies in individual years according to the statistical classification of economic activities in Slovakia- SK NACE, which were included in the analyzed sample, are given in Table 3.

Table 3. Number of limited liability companies according to SK NACE for the period 2014-2018

\begin{tabular}{|l|c|c|c|c|c|}
\hline SK NACE & $\mathbf{2 0 1 4}$ & $\mathbf{2 0 1 5}$ & $\mathbf{2 0 1 6}$ & $\mathbf{2 0 1 7}$ & $\mathbf{2 0 1 8}$ \\
\hline 55100 Hotel and similar accommodation & 820 & 828 & 837 & 863 & 876 \\
\hline 55200 Tourist and other short-stay accommodation & 428 & 442 & 502 & 562 & 639 \\
\hline 55300 Caravans, camps and caravan sites & 22 & 21 & 21 & 20 & 22 \\
\hline 55901 Accommodation in dormitories & 5 & 5 & 5 & 4 & 4 \\
\hline $\begin{array}{l}\text { 55909 Accommodation in hostels and other temporary } \\
\text { accommodation }\end{array}$ & 243 & 247 & 261 & 274 & 311 \\
\hline 56100 Restaurants and mobile food service activities & 2 & 2 & 0 & 0 & 0 \\
\hline 56101 Canteens & 619 & 675 & 743 & 844 & 975 \\
\hline 56102 School catering facilities & 5 & 6 & 6 & 6 & 8 \\
\hline 56109 Other food service activities & 762 & 783 & 826 & 881 & 910 \\
\hline 56210 Food delivery services & 163 & 170 & 183 & 208 & 221 \\
\hline 56290 Other food service activities & 608 & 652 & 681 & 731 & 791 \\
\hline 56300 Hospitality services & 3247 & 3322 & 3451 & 3658 & 3916 \\
\hline Total & $\mathbf{6 9 2 4}$ & $\mathbf{7 1 5 3}$ & $\mathbf{7 5 1 6}$ & $\mathbf{8 0 5 1}$ & $\mathbf{8 6 7 3}$ \\
\hline
\end{tabular}

Source: own calculations based on data from the register of FS for the accounting period 2014-2018 (Finstat, 2020)

Selected statistical indicators (minimum value, maximum value, median, and average) of the equity of the analyzed sample of companies in Slovakia for the examined period 2014-2018 are shown in Table 4. 
Table 4. Selected statistical indicators of the sample of companies in the period 2014-2018 in $€$

\begin{tabular}{|l|c|c|c|c|c|}
\hline $\begin{array}{l}\text { Statistical } \\
\text { indicator of } \\
\text { equity }\end{array}$ & 2014 & 2015 & 2016 & 2017 & 2018 \\
\hline Min & $-13,833,541$ & $-13,915,455$ & $-13,947,195$ & $-13,954,397$ & $-13,960,569$ \\
\hline Max & $32,378,400$ & $101,276,000$ & $106,091,000$ & $115,349,000$ & $122,922,000$ \\
\hline Median & $\mathbf{2 , 3 5 8}$ & $\mathbf{3 , 0 4 1}$ & $\mathbf{3 , 5 4 8}$ & $\mathbf{4 , 0 4 0}$ & $\mathbf{3 , 9 6 1}$ \\
\hline Average & $\mathbf{1 0 , 9 3 1}$ & $\mathbf{5 5 , 4 2 0}$ & $\mathbf{6 5 , 4 2 8}$ & $\mathbf{7 1 , 2 2 4}$ & $\mathbf{7 3 , 1 3 9}$ \\
\hline
\end{tabular}

Source: own calculations based on data from the register of FS for the accounting period 2014-2018

(Finstat, 2020)

Based on the information from the financial statements of limited liability companies, the authors analyzed the development of equity for the period 2014-2018. It is clear from Table 4 that the minimum equity value during the monitored period is negative, which means, that the business finances its activities, especially through extraneous resources, not automatically facing bankruptcy if it is not a long-term state. Hendl (2015) states that the calculation of the Pearson correlation coefficient is performed from $\mathrm{n}$ pair values (xi, yi), while the estimate of its theoretical value is the selected Pearson correlation coefficient $r(X, Y)(1)$.

$$
r(X, Y)=\frac{s(X, Y)}{s(X) s(Y)}
$$

The correlation coefficient can take a value from the interval $-1<\mathrm{r}(\mathrm{X}, \mathrm{Y})<+1$, and if it is equal to zero, then there is no relationship between the investigated quantities. The individual levels of the correlation coefficient values are interpreted in Table 5.

Table 5. Interpretation of Pearson correlation coefficient values

\begin{tabular}{|l|l|}
\hline The value of the correlation coefficient & Interpretation \\
\hline $0.90-1.00(-1.00$ to -0.90$)$ & very high correlation \\
\hline $0.70-0.90(-0.90$ to -0.70$)$ & high correlation \\
\hline $0.50-0.70(-0.70$ to -0.50$)$ & medium correlation \\
\hline $0.30-0.50(-0.50$ to -0.30$)$ & low correlation \\
\hline $0.00-0.30(-0.30$ to 0.00$)$ & very low or no correlation \\
\hline
\end{tabular}

Source: Hinkle et al., 2003

In the research, the authors used debt ratios, specifically the authors examined the total indebtedness and the degree of self-financing, based on which the authors assess whether limited liability companies have enough own resources to finance their activities.

Due to the onset of the COVID-19 pandemics at the beginning of 2020, entrepreneurs had the opportunity to postpone the filing of income tax returns and the publication of financial statements, which a large number of companies used, so data for 2019 were not included in the analyzed sample. Therefore, the impact of the pandemics was not reflected in the analyzed data but expresses the peak of the development of the tourism industry in the Slovak Republic.

\section{RESULTS}

In terms of assessing the impact of the segment on the country's economy, it can be based on the share of the sector in GDP in individual years. The average value of the direct gross domestic product of tourism (GDP of tourism) in the Slovak Republic, representing the sum of direct gross value added of tourism and net taxes on tourism products in the period from 2014 to 2018 
reached on average $2.55 \%$ of GDP of the Slovak economy per year (Figure 2), while the largest share was in the last analyzed year 2018.

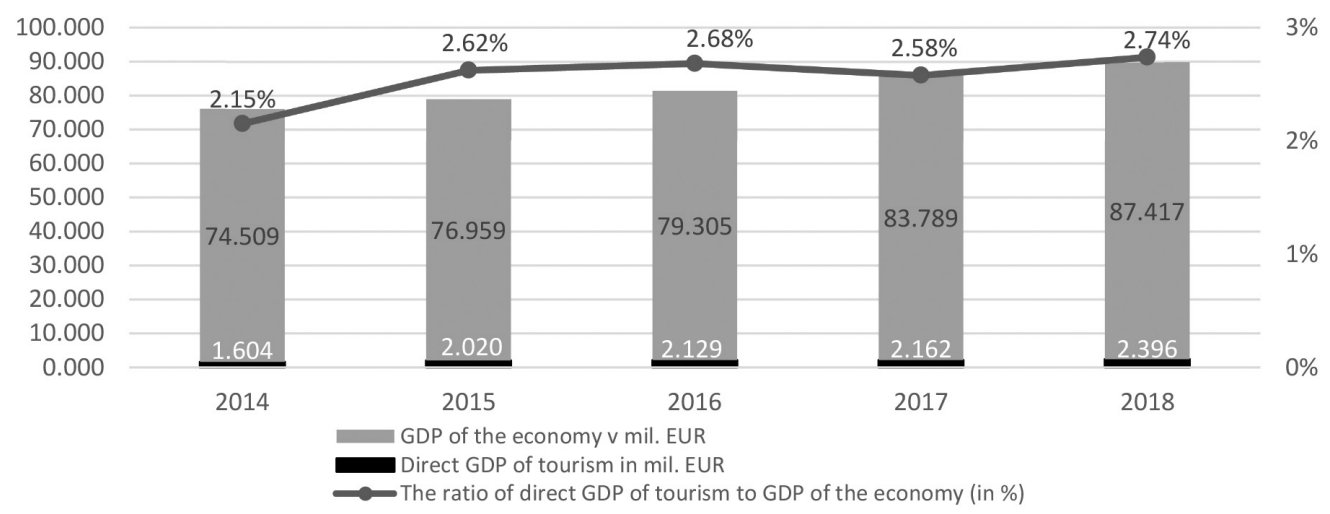

Figure 2. The share of direct GDP of tourism in the GDP of the Slovak economy

Source: Statistical Office of the Slovak Republic, 2020

During the period under review, visitors spent an average of around $€ 5.058$ billion on domestic, outbound, and inbound tourism (Statistical office of the Slovak Republic, 2020), with visitors spending the most in 2018 (on average around $€ 5.856$ billion). In the Slovak Republic, several comprehensive visitor consumption indicators are distinguished for different forms of tourism (Šenková \& Šambronská, 2014):

- home tourism, respectively domestic tourism consumption is the consumption of resident visitors in the monitored country and may include products or services produced in a foreign or produced by non-residents, but sold in the country under review (imported products and services),

- inbound tourism, respectively inbound tourism consumption is the consumption of non-resident visitors in the economic territory of the country pursued (Slovakia), while the products and services purchased in the monitored country may be imported,

- outbound tourism, respectively outbound tourism consumption is the consumption of resident visitors outside the economic territory of the monitored country and does not include products and services purchased on the journey or by journey in the monitored country,

- internal tourism, respectively internal tourism consumption consists of the overall consumption of resident and non-resident visitors on the economic territory of the monitored country. It is the sum of domestic tourism consumption and inbound tourism consumption. It may include products and services imported into a monitored country and sold to visitors,

- national tourism, respectively national tourism consumption consists of the total consumption of resident visitors on the economic territory of the monitored country and outside this territory. It is the sum of domestic tourism consumption and outbound tourism consumption. These purchases may relate to products and services made in the monitored country or products and services imported from non-resident producers,

- total visitors' consumption is understood as the amount of total consumer expenses incurred by visitors or on behalf of the visitor to the journey or during his journey and stay in a given destination. All product and service categories are included in this consumption.

In all forms of tourism, i.e. in domestic, outbound, and inbound tourism, the majority of expenditures for the examined period were tourists representing overnight visitors; specifically in inbound tourism, tourists represented overnight stays on average for $69 \%$ of total expenditures, 
in outbound tourism, the share of expenditures of these tourists corresponded to an average of about $90 \%$, and in domestic tourism, the share of expenditures represented an average of about $64 \%$ of total expenditures. The remaining part was represented by one-day tourists representing visitors without an overnight stay, whose share in total expenditures in inbound tourism averaged about $31 \%$, in outbound tourism the average amount of one-day tourists was about $10 \%$, and in domestic tourism, the share of expenditures of these tourists averaged $36 \%$ (Figure 3).

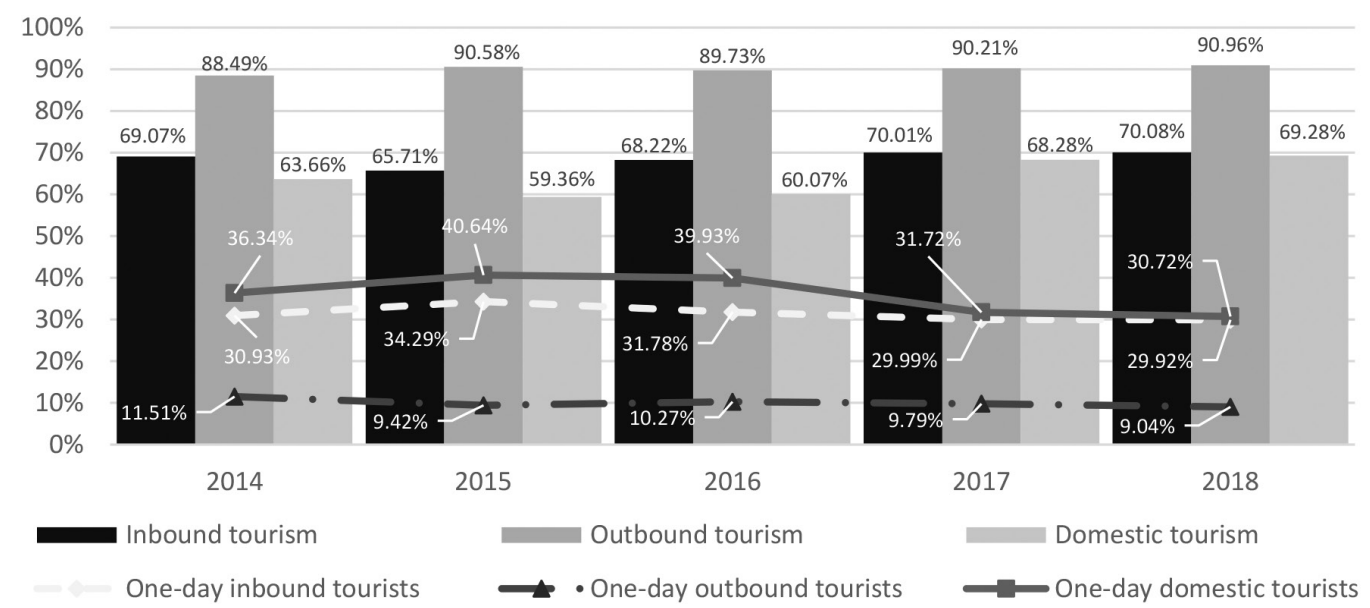

Figure 3. Expenditures in tourism by category of visitors (tourists/day trips)

Source: own processing based on data from the Statistical Office of the Slovak Republic, 2020

The main goals of any business entity from the financial point of view are to make a profit and to maximize the value of the business for a long period. Profit is a positive result of management, which arises when revenues for the accounting period are higher than costs. The result of management represents according to section 2(4)h) of the Accounting Act (2020), the effect of the accounting entity's activities achieved in the accounting period. Profit or loss is the accounting entity's own resource, distinguishing between profit or loss for previous years and profit or loss for the accounting period after tax. In the years 2014-2018, the analyzed sample of companies achieved a cumulative economic result in the form of a loss, which reduced the amount of equity, while from 2014 to 2017 the loss gradually leveled off. In 2018, the loss increased again (Figure 4).

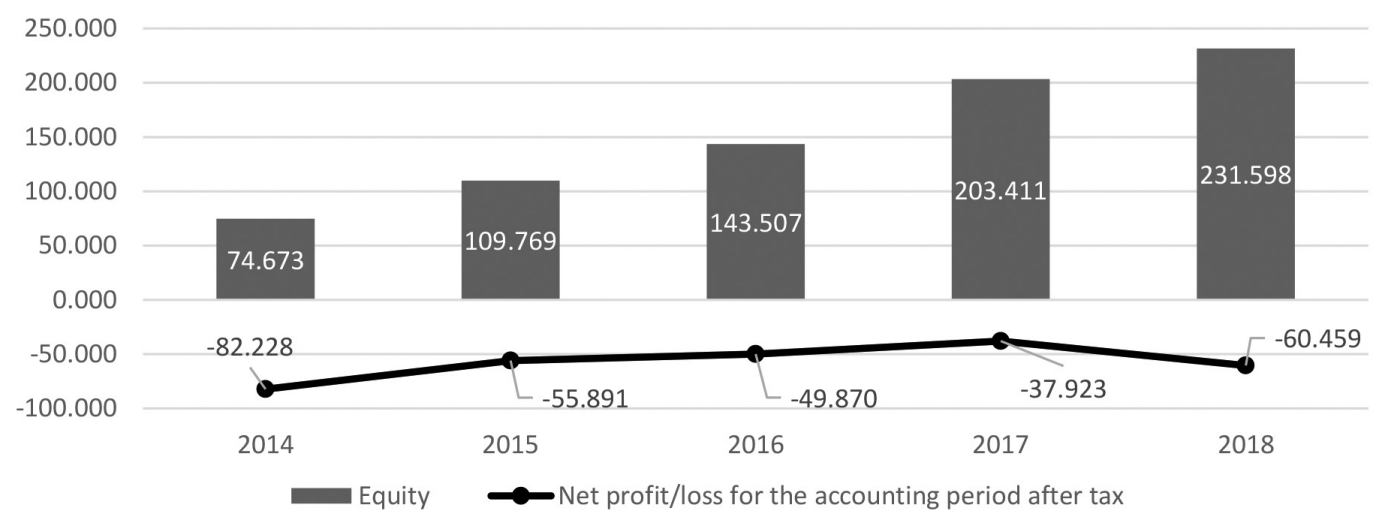

Figure 4. Profit after tax and equity in limited liability companies (in thousands of $€$ )

Source: own calculations based on data from the register of FS for the accounting period 2014-2018

(Finstat, 2020)

It follows from figure 4 that in 2018 the analyzed limited liability companies reached the highest value of the loss, namely 60,459 thousand $€$. 
The highest value of the profit after tax was achieved by limited liability companies in 2016, specifically in the amount of $€ 43,652,770$. In terms of average values of the economic result, it can be assessed that the loss decreased from 2015 to 2017. In 2018, it increased by almost $€$ 5,000 (Table. 6).

Table 6. Selected statistical indicators of profit after tax in $€$ of the sample of companies

\begin{tabular}{|l|c|c|c|c|c|}
\cline { 2 - 6 } \multicolumn{1}{c|}{} & $\mathbf{2 0 1 4}$ & $\mathbf{2 0 1 5}$ & $\mathbf{2 0 1 6}$ & $\mathbf{2 0 1 7}$ & $\mathbf{2 0 1 8}$ \\
\hline Min & $-12,819,135$ & $-24,829,389$ & $-9,302,515$ & $-5,187,658$ & $-3,164,843$ \\
\hline Max & $2,387,339$ & $2,113,150$ & $43,652,770$ & $11,318,699$ & $7,573,000$ \\
\hline Median & -503 & -503 & -480 & -480 & -335 \\
\hline Average & $-12,361$ & $-12,377$ & $-6,582$ & $-2,753$ & $-7,218$ \\
\hline
\end{tabular}

Source: own calculations based on data from the register of FS for the accounting period 2014-2018

(Finstat, 2020)

Given that the profit after tax is only one of the items of equity, its negative value may not have the most significant impact on the total amount of equity, which also follows from Figure 4, when the loss did not have a significant effect on the total amount of equity. In addition to the aforementioned profit or loss, own resources also include share capital, capital funds, funds created from profit, and profit or loss from previous years. In the analyzed sample of companies, the largest part of equity was formed by capital funds, the amount of which in the examined period reached a value in the range from 322,830 thousand $€$ to 439,711 thousand $€$ and increased every year, which means that the value of equity was positively affected mainly by the contributions of owners, other than share capital, which is mandatory in the legal form of limited liability companies. The increase in capital funds means that investors in the examined sector believed in the future and were willing to take a business risk.

The value of equity in the examined period is negatively affected due to the economic result of previous years (cumulated unpaid losses) and the economic result for the actual accounting period after-tax (loss of the current period), the accumulated value of which is negative in the examined companies (Figure 5).

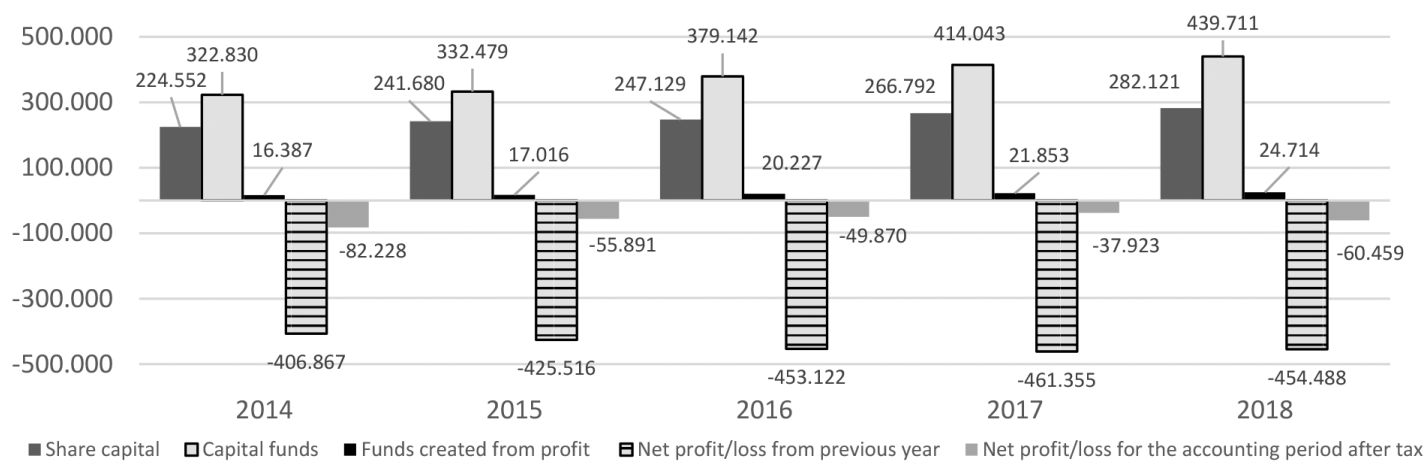

Figure 5. Development of individual equity items in limited liability companies (in thousands of $€$ )

Source: own processing based on data from the register of FS for the accounting period 2014-2018

(Finstat, 2020)

Based on the results of a correlation analysis performed on a sample of companies operating in the field of tourism, a very high correlation can be identified between equity and share capital (0.99), both between equity and capital funds (0.99), and last but not least between equity and funds created from profit (0.99), where the value of correlation coefficient reached the same val- 
ue. Furthermore, it can be stated that there is a high dependence $(-0.88)$ between equity and the result of previous years. The value of the correlation coefficient in the case of equity and profit for the accounting period after tax reached the amount of 0.60 , based on which it is possible to state a medium dependence between the mentioned elements. The above facts also confirmed the graphical dependence, where we can see a parallel linear course of changes in individual components of equity and opposite to net profit/loss from the previous year (Figure 6).

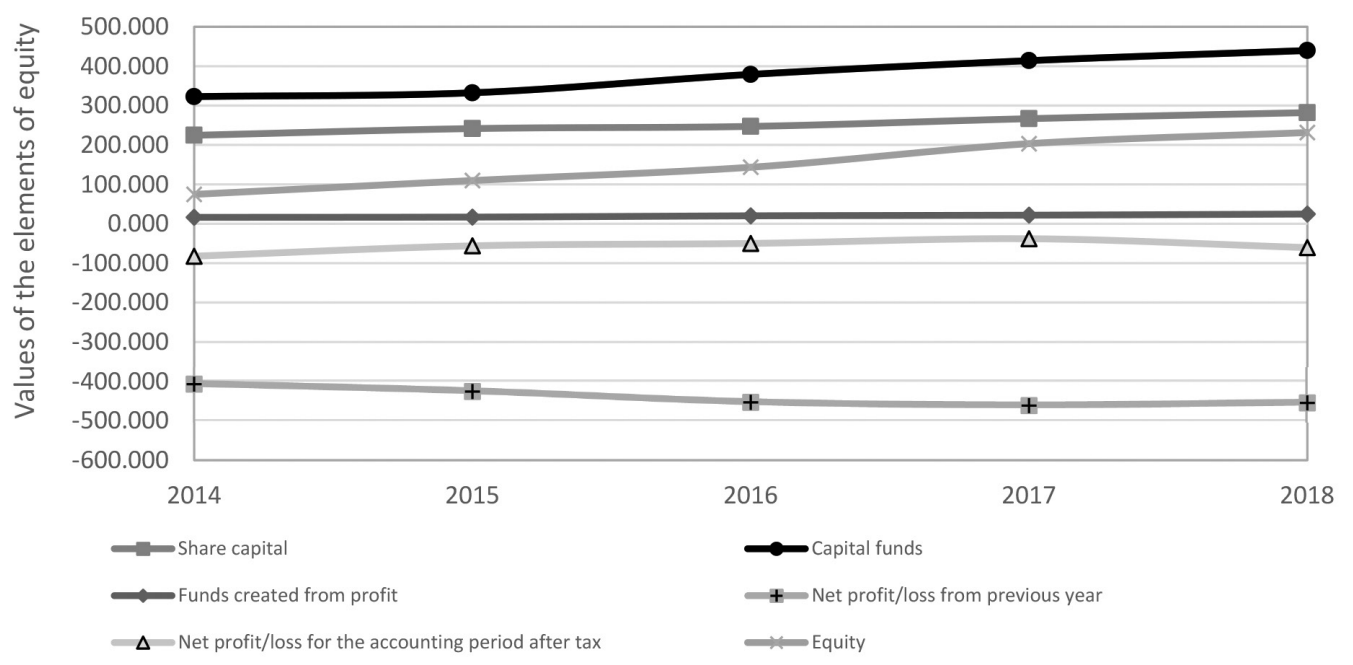

Figure 6. Dependence of equity and its individual items (in thousands of $€$ )

Source: own processing based on data from the register of FS for the accounting period 2014-2018

(Finstat, 2020)

In connection with the financing of the individual needs of the company, it is important to analyze the total indebtedness and the degree of self-financing of the company. Total indebtedness expresses the financing of the company's assets through external resources, i.e. liabilities. The opposite indicator is the degree of self-financing expressing the degree of financing of the company's assets through its own resources, i.e. equity. The sum of both mentioned indicators is equal to $100 \%$. In the examined companies, they cumulatively exceed their liabilities over equity, which means that they do not have enough of their own resources to finance their activities. The value of total indebtedness in the examined period 2014-2018 has a decreasing tendency, and on the contrary, the degree of self-financing increases, while in 2018 own resources account for 13\% of total resources, which is also the highest value of this indicator in the examined period (Figure 7).

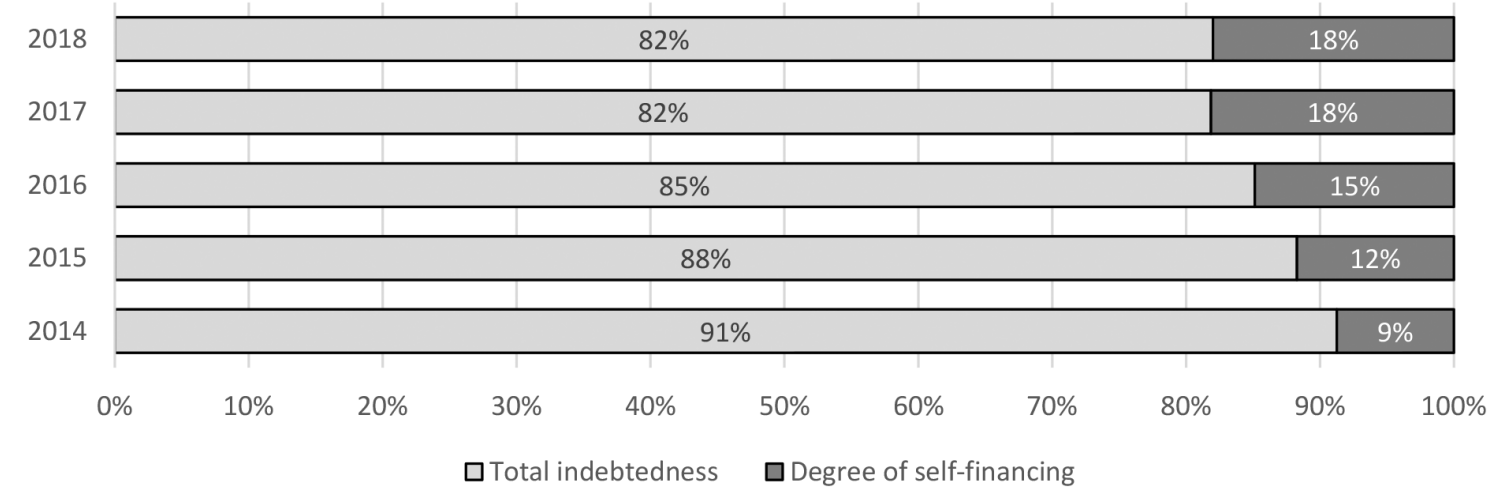

Figure 7. Total indebtedness and degree of self-financing in limited liability companies Source: own processing based on data from the register of FS for the accounting period 2014-2018

(Finstat, 2020) 
In the statistical examination of indebtedness indicators, it can be assessed that based on average values of equity and liabilities, companies are in debt during the examined period, while the average value of total indebtedness ranges from $79 \%$ to $95 \%$. Based on the minimum values, it is clear that the total indebtedness is decreasing, the value of which has reached $1 \%$ since 2017. Statistical indicators of the sample of companies are shown in Table 7.

Table 7. Selected statistical indicators of the total indebtedness of the sample of companies

\begin{tabular}{|l|c|c|c|c|c|}
\cline { 2 - 6 } \multicolumn{1}{c|}{} & $\mathbf{2 0 1 4}$ & $\mathbf{2 0 1 5}$ & $\mathbf{2 0 1 6}$ & $\mathbf{2 0 1 7}$ & $\mathbf{2 0 1 8}$ \\
\hline Min & $2 \%$ & $2 \%$ & $2 \%$ & $1 \%$ & $1 \%$ \\
\hline Max & $42 \%$ & $80 \%$ & $71 \%$ & $72 \%$ & $75 \%$ \\
\hline Median & $93 \%$ & $91 \%$ & $90 \%$ & $89 \%$ & $90 \%$ \\
\hline Average & $95 \%$ & $85 \%$ & $81 \%$ & $79 \%$ & $79 \%$ \\
\hline
\end{tabular}

Source: own processing based on data from the register of FS for the accounting period 2014-2018

(Finstat, 2020)

In the case of the degree of self-financing calculated based on the median values, it follows that in the examined period the degree of self-financing of half of the companies was equal to or higher than 7 to $11 \%$, and in the case of the other half of companies, the degree of self-financing was equal to or lower than 7 to $11 \%$ (Fig.7).

As mentioned above, at the end of 2019, the first reports from China about coronavirus appeared, which negatively affected business not only in Slovakia but also around the world, which so far has largely affected the tourism industry in particular.

\section{PRESENT TOURISM INDUSTRY IN THE SLOVAK REPUBLIC DURING THE COVID-19 PANDEMICS}

The pandemics of the COVID-19 disease in the Slovak Republic, as well as in other countries (Grmelová, 2020) affected the tourism industry the most due to restrictions on movement, either due to restrictive measures of the Slovak government or due to natural fear of people. There has been a radical halt to the global movement of people, essentially overnight, and it is still unclear when and whether this movement will reach pre-pandemic levels at all. The basic feature of tourism is traveling, visiting, getting to know new areas, cultures, and customs on the spot, which is associated with the movement of people. Before the pandemics, such travel became affordable for an ever-increasing group of Slovaks, who also made extensive use of it (Štrba et al., 2020; Onuferová et al., 2020; Matijová, 2019). This applied not only to travel within the country but also to travel abroad, where the price of air tickets was often so low that anyone could travel. The tourism industry grew rapidly and this was also evident from the growing number of accounting entities in the examined industry segments.

At the time of the pandemics, the sectors examined are among the most affected by the restrictions. A total of 15,660 companies directly endangered by the coronavirus operate in Slovakia, with annual revenues of $€ 8.7$ billion. Most companies are engaged in hospitality services $(3,933$ companies), all of which are affected by restrictions. Of the 3,933 companies, 3,315 companies were active, with sales of $€ 539,690,759$, with a median of revenues $€ 45,184$ (Finstat, 2020). The histogram of sales of companies operating in the area of SK NACE 56300 Hospitality services (included in our examined sample) as of March 26, 2020 is shown in Figure 8. 


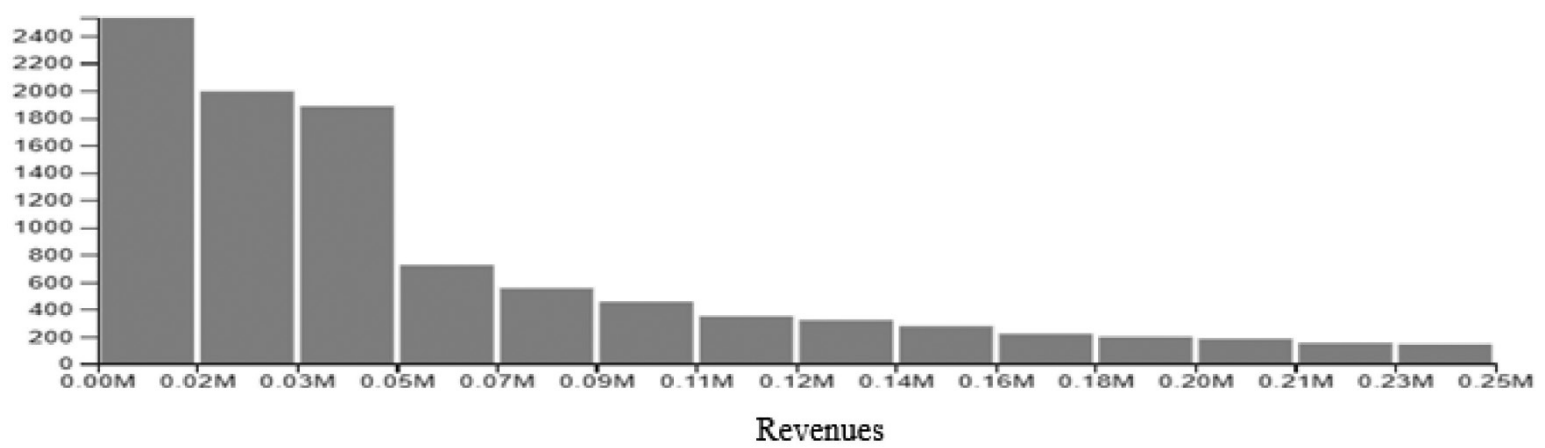

Figure 8. Histogram of revenues of companies providing hospitality services

Source: Finstat, 2020

As of the date of the analysis (Finstat, 2020), most companies providing hospitality services that are affected by coronavirus operate in the Bratislava region $(1,108)$. These companies achieve revenues in the region in the amount of 200,314 thousand $€$, with the median of 56,391 thousand $€$. On the contrary, the smallest representation is held by companies in the Trnava region, where there are 319 companies providing hospitality services. The smallest revenues are achieved by companies in the Trenčín region, specifically in the amount of 32,908 thousand $€$, while the median of revenues is 37,955 thousand $€$ (Figure 9).

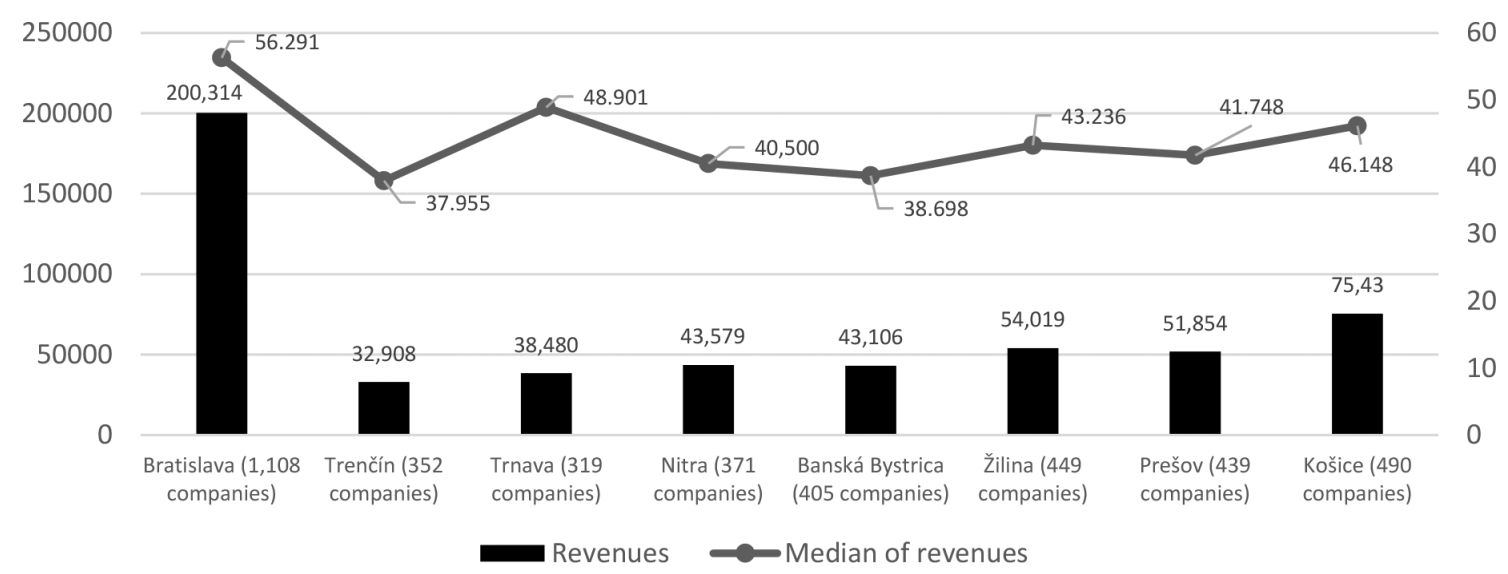

Figure 9. Revenues and median of revenues of companies providing hospitality service in thousands $€$

Source: own processing based on information from Finstat, 2020

Currently, since October 2020, the Slovak government has adopted stricter measures related to restrictions in some business sectors, but also in the cultural and sports sectors, due to the deteriorating epidemiological situation and the onset of the second wave of the COVID-19 pandemics. Since mid-October, the measures have been the most restrictive to business operating restaurants, bars, cafes. Public catering establishments are not closed, but food and drinks can only be served outdoors if they have such a space (for example, on a terrace where at least one wall must be open, which is not realistic in the winter months), respectively food and drinks can be released hygienically wrapped with them through the window as during the first wave of the pandemics. They cannot serve food indoors and customers cannot consume it there either. The outdoor terraces are completely closed from mid-December. There is also a reduction in the gathering of people in one place, which has also affected mass caterers, various event agencies, conference services, cultural facilities, sporting and tourism events. 


\section{FUTURE RESEARCH DIRECTIONS}

The subject of future research is the analysis of equity and its individual items of companies providing accommodation, restaurant and hospitality services in 2020 when 2 waves of coronavirus pandemics broke out in Slovakia. The first wave appeared in early March, with a state of emergency declared in mid-March, which resulted in the closure of accommodation, restaurant and hospitality businesses, as well as in several related sectors of the tourism industry, in particular the operation of travel agencies and guide services, which will also be the subject of future analysis. At the beginning of June, the situation began to calm down, measures were gradually relaxed and many companies restarted their operations. The second wave occurred in mid-September when new measures were introduced and travel was restricted, which again harms many businesses. During the pandemics, the Government of the Slovak Republic tries to provide various support for entrepreneurs, which can alleviate the manifestations in the financial situation. All these effects will be possible to evaluate based only on financial data for the accounting period of 2020 , so the future analysis will be beneficial mainly due to the evaluation of the effects of both restrictive and supporting measures of the Slovak government on the tourism industry.

\section{CONCLUSION}

Equity is the company's own resources, which it has at its disposal for a long time. The most important component of equity is considered to be the share capital, which according to the Commercial Code valid in the Slovak Republic is a monetary expression of the sum of monetary and non-monetary contributions of all shareholders to the company. All components of equity are reported in the financial statements in the financial statements Balance sheet on the liabilities side. Accounting entities in the Slovak Republic publish financial statements via the Internet on the Register of Financial Statements website (https://www.registeruz.sk/).

The aim of this chapter was based on the development of the total value of equity of a selected sample of companies operating in the Slovak Republic in the tourism sector in the period 20142018, to identify equity items that caused a change in equity with an emphasis on assessing the development of tourism industry in Slovakia to assess the adequacy of the number of own resources needed to finance the activities in the sector in the Slovak Republic based on indebtedness indicators.

The analysis shows that the value of the direct gross domestic product of tourism (GDP tourism) in 2018 reached 2.74\% of the GDP of the Slovak economy (Statistical Office of the Slovak Republic, 2020), while in all forms of tourism, i.e. domestic, outbound and inbound tourism accounted for the predominant part of expenditures for the examined period by overnight tourists and the remaining part was represented by overnight tourists without overnight stays.

Based on the analysis performed on a sample of companies for the period 2014-2018, it can also be stated that the total amount of equity for the entire sample reached positive values. Although the examined companies made a cumulative loss in the period under review, the cumulative development of equity did not decrease, on the contrary, the value of equity increased every year. Loss is only one of the items of equity, so further analysis of individual items of equity is needed, as a result of which it increases. Such an item may include capital funds in the examined companies, which accounted for the largest share of equity in the period under review. 
Capital funds and their growth mean the replenishment of equity by additional contributions from shareholders, which means that investors in the examined sector believed in the future and were willing to take a business risk.

The results of the correlation analysis confirmed the existence of very high dependence of equity and share capital, capital funds, and funds created from profit, where the value of the correlation coefficient reached a value equal to 0.99 . At the same time, the correlation analysis identified the existence of high dependence on equity and profit or loss from previous years $(-0.88)$ and a medium dependence between equity and profit for the accounting period after tax $(0.60)$.

At the same time, it can be stated from the performed analysis that the liabilities in the examined companies significantly exceed the equity. It follows that the analyzed companies do not have sufficient own resources to finance their business activities, although the degree of self-financing tended to increase during the period under review, mainly due to additional contributions from owners. In 2018, own resources accounted for only 18\% of total resources.

Because at the turn of 2019 and 2020 the coronavirus spread from China to the whole world, it is not possible to predict further future effects respectively impacts on the activities of the examined companies, as the situation is constantly changing. It was confirmed that the tourism industry is currently one of the most endangered sectors of industry in the Slovak Republic. It can be assumed that a large number of entrepreneurs in this sector will close down due to the bad financial situation and especially due to the pandemics and the sociological consequences resulting from the concern of tourists and customers. Nevertheless, if entrepreneurs want to continue their activities, they should try to increase the volume of their own resources, for example through additional contributions from shareholders. Another possibility to increase own resources is to acquire a silent partner (Hrinková \& Manová, 2017).

\section{ACKNOWLEDGMENT}

This research was supported by projects no. I-21-103-00 and APVV-16-0602.

\section{REFERENCES}

Act No. 431/2002 Coll. on accounting, as amended.

Act No. 513/1991 Coll., Commercial Code, as amended.

Ashworth, J. \& Thomas, B. (1999). Patterns of Seasonality in Employment in Tourism in the UK, Applied Economics Letters, 6(11), 735-739.

Beránek, J. (2013). Tourism economy. Praha: mag CONSULTING.

Brida, G. H., Barquet, A. \& Risso, A. W. (2010). Causality between economic growth and tourism expansion: empirical evidence from Trentino-Alto Adige, Tourismos: An International Multidisciplinary Journal of Tourism, 5(2), 87-98.

Brida, J. G., Pereyra, J. S., Such Devesa, M. J. \& Zapata Aguirre, S. (2008). La contribución del turismo al crecimiento económico. Cuadernos de Turismo, 22, 35-46.

CDB SK (2020). Map of regions in Slovakia. Retrieved from: https://www.cdb.sk/sk/VystupyCDB/Mapy-cestnej-siete-SR/Mapy-krajov.alej.

Claveria, O. \& Datzira, J. (2009). Tourism demand in Catalonia: detecting external economic factors, Tourismos: An International Multidisciplinary Journal of Tourism, 4(1), 13-28. 
Cvik, E., D. \& MacGregor Pelikánová, R. (2015). Economy and Management of Czech Cohesion Regions - Who is at Blame? p. 46-54 In: Jedlička, P. (Ed.) Peer-Reviewed Conference Proceedings - International Conference Hradec Economic Days 2015, Vol. 4, 3rd-4th February, 2015, Hradec Králové, Czech Republic: Gaudeamus, 2015, 46-54.

Čačić, K. (2013). Poslovanje hotelskih preduzeća. Beograd: Univerzitet Singidunum.

Dobre, R. (2005). Počela turizma, Šibenik: Visoka škola za turistički menadžment.

European Union (2020). Member countries of the EU. Retrieved from: https://europa.eu/european-union/about-eu/countries_en.

Fernández-Moralez, A. (2003). Decomposing seasonal concentration, Annals of Tourism Research, 30(4), 942-956.

Finstat. (2020). Dataset of financial information of companies from SR for 2014 - 2018. Available at: www.finstat.sk.

Gligorijević, Ž. \& Stefanović, V. (2012). Turizam kao društveno-ekonomski fenomen: pojmovni i vremenski obuhvat, Ekonomske teme, 50(3), 269-282.

Goeldner, C., Ritchie, B. \& McIntosh, R. (2000). Tourism: Principles, Practices, Philosophies. New Jersey: John Wiley \& Sons.

Grmelová, N. (2020). The Catholic Church as an Entrepreneur in the Czech Republic. Právo $v$ podnikání vybraných členských států Evropské unie - sborník př́spěvků z XII. ročniku mezinárodní vědecké konference, 1. vydání. Praha: TROAS s. r. o.

Gúčik, M. (2011). Tourism - Politics and Economics. Banská Bystrica: Dali BB.

Hendl, J. (2015). Overview of statistical methods: data and meta-analysis. Praha: Portál.

Hinkle, D. E., Wiersma, W. \& Jurs S. G. (2003). Applied statistics for the behavioral sciences. Boston: Houghton Mifflin.

Hrinková, K. \& Manová, E. (2017). Sources of financing of the business assets, Journal of innovations and applied statistics, 7(3), 19-25.

Holický, M. (2015). Applications of probability theory and mathematical statistics. Praha: České vysoké učení technické.

Juul, M. (2015). Tourism and the European Union. Recent Trends and Policy Developments. European Parliamentary Research Service: Brussels, Belgium.

Kučerová, J., Strašík, A. \& Šebová, L. (2010). Tourism Business Economy. Banská Bystrica: Univerzita Mateja Bela.

Lundberg, D. E., Krishamoorthy, M. \& Stavenga, M. H. (1995). Tourism economics. New York: John Wiley and Sons Inc.

MacGregor Pelikánová, R. (2019). Harmonization of the protection against misleading commercial practices: ongoing divergences in Central European countries. Oeconomia Copernicana, 10(2), 239-252. DOI: 10.24136/oc.2019.012

MacGregor Pelikánová, R. \& MacGregor, R. (2017). European e-Justice Portal - Reality of Electronic One-Stop-Shop for Publication of Financial Statements in the EU. In: Jindřichovská, I.; Kubičková, D. Conference: 5th International Scientific Conference on IFRS Global Rules and Local Use Location: Anglo Amer Univ, Prague, CZECH REPUBLIC Date: OCT 20, 2017. IFRS: GLOBAL RULES \& LOCAL USE, 98-111.

Matijová, M., Onuferová, E., Rigelský, M. \& Stanko, V. (2019). Impact of Selected Indicators of Tourism Capacity and Performance in Context of the Unemployment Rate in Slovakia, Journal of Tourism and Services, 10(19), 1-23.

Máziková, K. et al. (2016). Business entities accounting I. Bratislava: Wolters Kluwer.

Measure of the Ministry of Finance of the Slovak Republic no. MF/23054/2002-92, which lays down the details of the accounting procedures and the general chart of accounts for entrepreneurs accounting in the double-entry bookkeeping system, as amended. 
Meyer, D. (2004). Economía Turística en América Latina y el Caribe. Colombia: Universidad Externado de Colombia.

Ministry of Labor, Social Affairs and Family SR (2020a). Pandemic plan of the Ministry of Labor, Social Affairs and Family of the Slovak Republic in case of a pandemic. Retrieved from: https://www.employment.gov.sk/sk/koronavirus-pracovna-socialna-oblast.

Ministry of Labor, Social Affairs and Family SR (2020b). "First aid and First aid plus". Retrieved from: https://www.pomahameludom.sk/.

Moreno, D. \& Tovar, N. (2015). Reflexiones y propuestas para un turismo responsable con enfoque de género. In ¿Equidad de Género en el Turismo? Muchas Sombras y Pocas Luces. Madrid: Foro de Turismo Responsible, 65-104.

Neumeier, S. \& Pollermann, K. (2014). Rural tourism as promoter of rural development - prospects and limitations: Case study findings from a pilot project promoting village tourism, European Countryside, 6(4), 270-296.

Onuferová E., Cabinová, V. \& Vargová T.D. (2020). Analysis of modern methods for increasing and managing the financial prosperity of businesses in the context of performance: a case study of the tourism sector in Slovakia, Oeconomia Copernicana, 11(1), 95-116.

Petrevska, B. \& Nikolovski, B. (2018). Level of seasonality in Macedonian tourism and strategies and policies for coping with it, 3rd International Thematic Monograph: Modern Management Tools and Economy of Tourism Sector in Present Era (pp. 17-29). Belgrade: Association of Economists and Managers of the Balkans with Faculty of Tourism and Hospitality, Ohrid, North Macedonia. https://doi.org/10.31410/tmt.2018.17.

Plog, S. (2001). Why destination areas rise and fall in popularity: An update of a Cornell Quarterly classic, The Cornell Hotel and Restaurant Administration Quarterly, 42(3), 13-24.

Register FS (2020). Register of financial statements 2014 - 2018. Available at: http://www.registeruz.sk/cruz-public.

Saarinen, J. (2006). Traditions of sustainability in tourism studies. Annals of Tourism Research, 33(4), 1121-1140.

Santos, A. \& Cincera, M. (2018). Tourism demand, low-cost carriers, and European institutions: The case of Brussels, Journal of Transport Geography, 73, 163-171.

Stanickova, M. \& Melecky, L. (2018). Understanding of resilience in the context of regional development using Composite index approach: The case of European Union NUTS-2 regions. Regional studies regional science, 5(1), 231-254.

Stanić, M. \& Vujić, T. (2016). Turizam kao faktor ekonomskog razvoja, Zbornik radova Univerzitet Sinergija, Bijeljina, 1(2), 14-19.

Steck, B., Wood, K. \& Bishop, J. (2010). Tourism: More Value for Zanzibar: value chain analysis: Final Report, Zanzibar.

Šambronská, K. (2017). Tourist products. Prešov: BOOKMAN.

Šapić, S., Filipović, J. \& Savić, J. (2018). The influence of habits and customs as elements of culture on consumer behavior in the sector of tourism, 3rd International Thematic Monograph: Modern Management Tools and Economy of Tourism Sector in Present Era (pp. 87-99). Belgrade: Association of Economists and Managers of the Balkans with Faculty of Tourism and Hospitality, Ohrid, North Macedonia. https://doi.org/10.31410/tmt.2018.87.

Šenková, A. \& Šambronská, K. (2014). Theoretical basis of measuring the impact of tourism on the national economy based on tourism satellite account. In Proceedings of Scientific Work Department of Economics and Economics, 52-64, Prešov: Prešovská univerzita.

Šlosárová, A. a kol. (2016). Accounting. Bratislava: Wolters Kluwer.

Šlosárová, A. (2018). Changes in presenting of equity items in balance sheet of entrepreneur and their impact on financial position of accounting entity. AIESA-budovanie spoločnosti 
založenej na vedomostiach: zborník: 16. medzinárodná vedecká konferencia: Bratislava, 5. - 6. november 2015, 376-386 Bratislava: Vydavatel'stvo EKONÓM.

Štefko, R., Gallo, P. \& Matušíková, D. (2018). Modern managerial methods and their potential in context of regional tourism development, 3rd International Thematic Monograph: Modern Management Tools and Economy of Tourism Sector in Present Era (pp. 101-114). Belgrade: Association of Economists and Managers of the Balkans with Faculty of Tourism and Hospitality, Ohrid, North Macedonia. https://doi.org/10.31410/tmt.2018.101.

Štrba, L., Kolačkovská, J., Kudelas D., Kršák B. \& Sidor, C. (2020). Geoheritage and Geotourism Contribution to Tourism Development in Protected Areas of Slovakia-Theoretical Considerations, Sustainability, 12(7), 1-20.

Statistical office of the Slovak Republic (2020). Tourism satellite account for 2018. Retrieved from: https://slovak.statistics.sk.

Turečková, K. and Nevima, J. (2019). Smart Approach in Regional Development. In: Proceedings of MIRDEC-12th, International Academic Conference Multidisciplinary and Interdisciplinary Studies on Social Sciences. Rome: University of Washington Rome Center, 77-84.

Valaskova, K., Lazaroiu, G., Olah, J., Siekelova, A. \& Lancova, B. (2019). How capital structure affects business valuation: A case study of Slovakia. Central European Business Review, 8(3), 1-17.

Wallace, G. \& Russel, A. (2004). Eco-cultural tourism as means for the sustainable development of culturally marginal and environmentally sensitive regions. Tourist Studies, 4(3), 235-254.

Zarebski, P., Kwiatkowski, G., Malchrowicz-Mośko, E. \& Oklevik, O. (2019). Tourism Investment Gaps in Poland. Sustainability, 11(22), 1-19. 